\title{
Phenetic Relationship of Lichen on African Wood Trees (Maesopsis eminii Engl.) in Tea Plantation of Tangsi Baru Village, Kabawetan District, Kepahiang District
}

\author{
RR Sri Astuti ${ }^{1}$ Tinra Ayu $^{2}$ Rochmah Supriati ${ }^{1, *}$ Evelyne Riandini ${ }^{1}$ \\ Fatimatuzzahra $^{1}$ \\ ${ }^{I}$ Department of Biology, Faculty of Mathematics and Natural Sciences, Universitas Bengkulu, Kandang Limun, \\ Bengkulu 38112, Indonesia \\ ${ }^{2}$ Undergraduate Student, Department of Biology, Faculty of Mathematics and Natural Sciences, Universitas \\ Bengkulu, Kandang Limun, Bengkulu 38112, Indonesia \\ "Corresponding author. Email: rsupriati@unib.ac.id
}

\begin{abstract}
Lichens are a mutually beneficial symbiosis between fungi and algae, they're found from lowlands to highlands. In a-highland Kepahiang Regency, lichens grown on various substrates; one of which is African wood trees (Maesopsis eminii. Engl). The study of the lichens diversity and their phenetic relationship aims to determine the diversity of lichens and to determine the phenetic relationship of lichens grown on African wood trees (Maesopsis eminii. Engl). Research was carried out in May-October 2020 at the Tea Plantation, Tangsi Baru Village, Kabawetan District, Kepahiang Regency. Sampling was carried out purposively to a height limit of $1.5 \mathrm{~m}$. Sample identification, herbarium preparation, and data analysis were carried out at the Plant Biosystematics Laboratory. Lichens were analyzed based on 53 character statuses, given scores, and converted into matrix data using the MS program. Excel and the UPGMA method (Unweight Pair Group Method with Arithmetic Average) program Numerical Taxonomy System (NTSYS) version 2.02. It was determined 31 species of lichens with 3 types of thallus; 13 species of crustose thallus, 12 species of foliose thallus, and 6 species of fruticose thallus. The lichens relationship phenogram showed a similarity coefficient ranging from 0.54 to 0.98 , divided into 2 main groups A and B. Main group A consisted of 22 species; 6 species of fruticose lichenes, 12 species of foliose lichenes and 4 species of crustose lichens. Main group B meanwhile, consisted of 9 species of crustose lichens. There were two species of one genus of lichens with a similarity coefficient of 0.98 which shows the similarity of almost all characters, namely Lecanora helva and Lecanora pulicaris. A distinguishing character is on the apothecia margin.
\end{abstract}

Keywords: Lichens, phenetic kinship, African Wood

\section{INTRODUCTION}

Kinship based on visible morphology is called phenetic kinship, which can be measured by comparing the status of morphological characters as much as possible [1]. [2] introduced the term phenetic to denote kinship relationships between living things based on the number of degrees of equality that exist based on the same morphological characters. The closer the kinship, the more similarities, the less the similarities, the further the kinship is [3].

The symbiosis between fungi and algae that is mutually beneficial is known as lichens [4]. Lichens can be found from lowlands to highlands, can be found on various substrates such as trees, man-made properties, rocks, and soil. Based on the thallus varieties lichens are divided into four types; fruticose lichens, foliose lichens, crustose lichens, and squamulose lichens. 


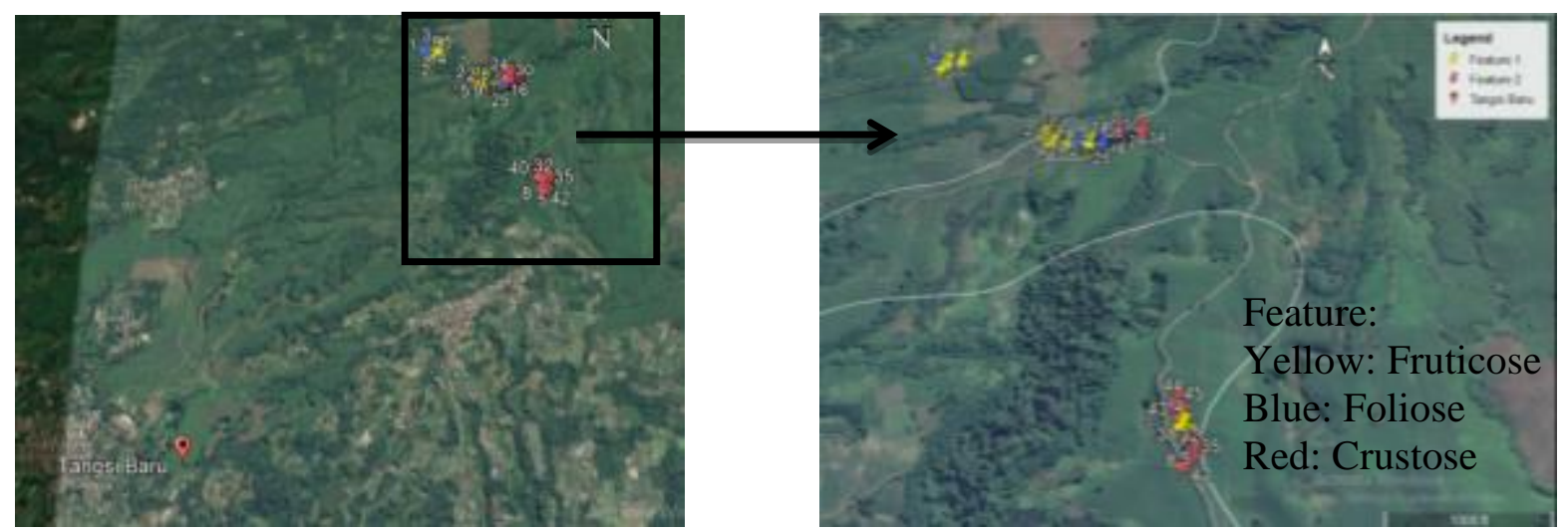

Figure 1. Map of Tangsi Baru Village Tea Garden Kabawetan District Kepahiang Regency (Google Earth)

The fruticose lichens have a bush-like shape, the foliose lichens have a sheet-like shape that is notched like a leaf, the crustose-type lichens have a crust-like shape and are tightly attached to the substrate surfaces, and the squamulose lichens have a shape like overlapping scales [5]. in Tangsi Baru Village, Kabawetan District, Kepahyang

Regency Bengkulu Provice, African wood trees (Maesopsis eminii Engl.) grown around Tea plantation. There were grown many kinds of lichens with various type of thallii, colour and its morfological characters. Until now, it was still lack of data reported about phenetic relationship on African wood trees in Tangsi Baru Village, Kabawetan District, so a study was conducted on "The Phenetic Relationship of Lichens grown on African Wood Trees (Maesopsis eminii Engl.) in Tangsi Baru Village Tea Plantation. Kabawetan District, Kepahiang Regency".

\section{MATERIALS AND METHODS}

Sampling of lichen (lichen) at African wood trees (Maesopsis eminii Engl.) was carried out since MayOctober 2020 in the Tea plantations, Tangsi Desa Baru subdistrict Kabawetan, Kepahiang District. The research method used was purposive sampling. The samples obtained were then identified based on their morphological characteristics in the Biosystematics Laboratory of Basic Science FMIPA, Bengkulu University, lichens were identified based on the literature of [1] The Lichens, [6] The Lichens of British Columbia.

Lichens are collected, grouped, and analyzed based on about 53 morphological character statuses, given a score, and converted into a data matrix using the MS Excel program. The similarity between groups of matrix data was analyzed using SIMQUAL (Similarity for qualitative Data) with a similarity coefficient SM (Simple Matching), then the similarity matrix used analysis grouping (Sahn) Sequential Angglome- rative, Hierarchical and Nested continued Clustering using UPGMA method (Unweight Pair Group Method with Arithmetic Average) in the Numerical Taxonomy System (NTSYS) version 2.02 [11].

\section{RESULTS AND DISCUSSION}

From the identification of lichens grown on African wood trees (Maesopsis eminii Engl.) In the Tea Plantations of Tangsi Baru Village, Kabawetan District, Kepahiang Regency, 31 species of lichens were determined, it was consisted 6 species of fruticose lichens, 12 species of foliose lichens and 13 species of crustose lichens. These lichens were determined as Ascomycota, that grouped in found on African wood trees, is included in Divisio Ascomycota, that grouped into 3 Classes, 5 Orders, 10 Families.

The most common lichens thallus found grown on African wood trees in Tangsi Baru Village Tea Plantation, those are the crustose thallus lichens (13 species). Some ideas supported this finding mentioned by researchers. According to [9] crustose lichens has tolerance to extreme environmental conditions so that it can adapt quickly to its surrounding environment. [10] adds that crustose thallus has a crust-like shape and is tightly attached to the substrate so that it requires less water for growth. This is the reason why thallus crustose lichens are found in large numbers at the study site.

According to [11] thallus crustose lichens grow well at an altitude of 0-3000 masl. The research site has an altitude of 900-1050 masl, this is one of the factors supporting the growth of lichens at the site. This is also supported by research conducted by [12] around the UIN ArRaniry campus where the crustose type lichens 
are most commonly found compared to other thallus types. [13], epiphytic lichens in the forest. Loang Gali tourism, Lenik Ramban Biak, East Lombok, there are 28 species of lichen with 16 species of thallus crustose and 12 species of talus foliose.

The least lichens found on African timber trees in the Tangsi Baru Village Tea Plantation are species with thallus fruticose; which was only 6 species exist. According to [7] fruticose lichens thallus is able to grow at an altitude above 700 masl, while the research location has an altitude of 9001050 masl. Little fruticose lichen was found due to the lack of a canopy formed on African timber trees because the trees were planted at a distance of more than 2 meters, so that the light intensity goes directly to the ground. fruticose lichen can grow well at low light intensity and air temperature moist ranged $18-21^{\circ} \mathrm{C}$. another factor that causes the least fruticose lichens allegedly due to the arrangement of the talus fruticose who cylinder, so the thallus structure attached to the substrates only slightly and is easily detached from its substrates when the wind blows. In this study, there was no found squamulose. lichen. This was because the abiotic factors at the research location did not support the growth of lichens with the squamulose type. According to [14], squamulose lichens are found in environments with high humidity and low temperatures with altitudes above 1600 masl. This is also supported by the research of [15] it was found the squamulose lichens were found in environments with a minimum temperature of $14^{\circ} \mathrm{C}$ and a maximum temperature of $26^{\circ} \mathrm{C}$. Whereas at the research location a minimum temperature of $21^{\circ} \mathrm{C}$ and a maximum temperature of $25^{\circ} \mathrm{C}$.

From the results of the phenogram formed, it can be seen that the farthest similarity coefficient is 0.54 and the closest similarity coefficient is 0.98. The similarity coefficient of 0.54 is divided into two main groups, namely group A and group B. Main group A consists of 22 species, 12 species including thallus foliose, six species of fruticose and four species of thallus crustose, main group B consists of nine species with type of thallus crustose. Similarity of characters in this group was found apothecia cup in several species. At a similarity coefficient of 0.60 , the main group A was separated into two groups, namely A1 and A2, the characters that separated this group were differences in the color of thallus, cilia, apothecia, and isidia.

Group A1 consists of 13 species of lichens, most of the lichens in this group have the foliose thallus type, only three species with the fruticose thallus type. The similarity of the characters in this group are not contained prothallus, rhizine, color rhizine, there are no apothecia, do not have labia, the color of the labia, do not have Perithecia, and type photobiont.

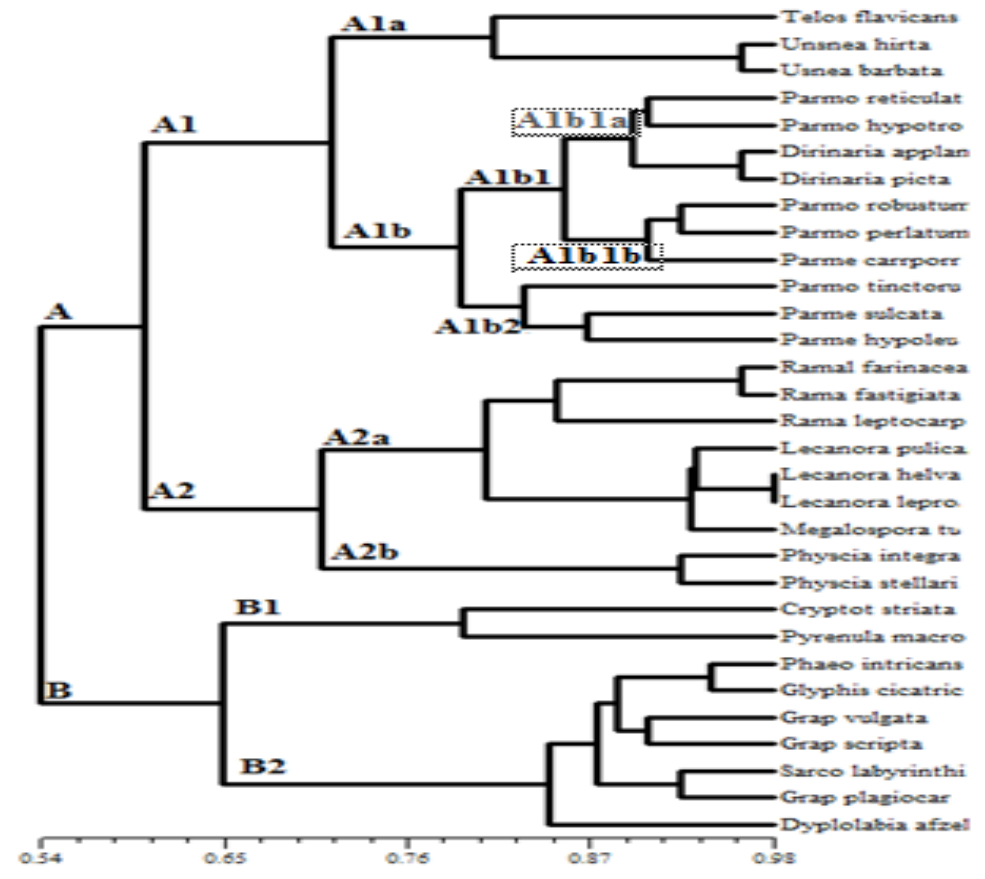

Figure 2. Phenogram of lichens based on the morphological characters 
The lichens in group A1 are separated into two groups A1a and A1b at a similarity coefficient of 0.70 , the characters that cause group A1 to separate are due to the type of thallus, variations in the thallus, and the type of rhizine.

Group A1a consisted of three species, namely Teloschistes flavicans, Usnea hirta and Usnea barbata. This group has similar morphological characters in the type of thallus, variations in the thallus, does not have a lower cortex, does not have a margin of the thallus, does not have a prothallus, does not have a lobe, has rhizine type umbilicus, does not have cilia, apothecia, apothecia lirellae, labia, isidia, and don't have perithecia. In this group Usnea hirta and Usnea barbata are closely related to the similarity coefficient of 0.96, distinguishing characteristics in the species is the color of the thallus above, and the number of fibrils.

Group A1b consists of 10 species, namely Parmotrema reticulatum, Parmotrema hypotropum, Dirinaria applanata, Dirinaria Picta, Parmotrema robustum, Parmotrema perlatum, Parmotrema tinctorum, Parmleia carrporrhizans, Parmelia sulcata, and Parmelia hypoleucina. The similarities of the characters in this group are the foliose thallus type, do not have prothallus, have lobes, have lobes, have simple black rhizine, do not have plate apothecia, do not have apothecia lirellae, do not have labia, have powder soredia, do not have perithecia and fibrils, photobiont type Trebouxia is green.

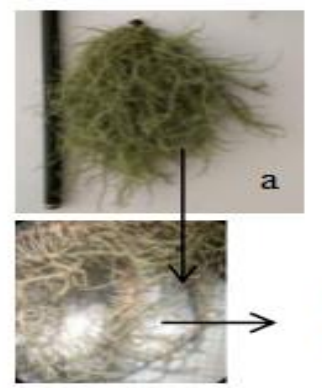

Talus is green in color, fibrils $\geq 30$

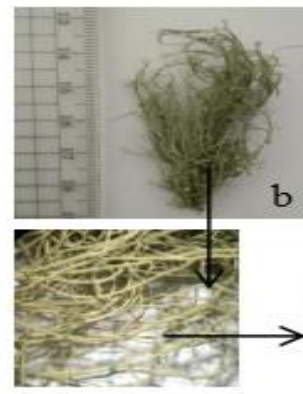

Talus is green-gray in color, fibrils $\leq 10$

Figure 3. Thallus structures of: a. Usnea barbata, b. Usnea hirta
At a similarity coefficient of 0.79 the $\mathrm{A} 1 \mathrm{~b}$ group is divided into two groups A1b1 and A1b2. Group A1b1 contained 7 species, namely, Parmotrema reticlatum, Parmotrema hypotropum, Dirinaria applanata, Dirinaria picta, Parmotrema robustum, Parmotrema perlatum, and Parmelia carrporrhizans. The distinguishing characters in this group are the thallus margin, the type of soredia, the color and location of the soredia. At the similarity coefficient of 0.82 , the A1b1 group was separated into two groups, namely the A1b1a group and the A1b1b group. In the A1b1a group Dirinaria apllanata and Dirinaria picta are included in the Parmotrema reticulatum and Parmotrema hypotropum groups because they have similar characters in the thallus margins, have rhizine, have cilia, do not have prothallus, apothecia, lirellae, labia, type soredia, do not have isidia, perithecia, fibrils, and photobiont. In this group the species Dirinaria picta and Dirinaria applanata are closely related with a similarity coefficient of 0.96 , the characters that distinguish Dirinaria applanata and Dirinaria picta are thallus color and soredia color.

In the group A1b1b Parmelia carrporrhizans include both Parmotrema robustum and Parmotrema perlatum have a similar character on the type of the thallus, the variation of the thallus, the color of the thallus, the color of the cortex below the margin of the thallus, rhizine, Cilia, do not have prothallus, fibrils, apothecia, and lirellae, has same photobiont type and color. In group A1b2 there are three species, namely, Parmotrema tinctorum, Parmelia hypoleucina and Parmelia sulcata.

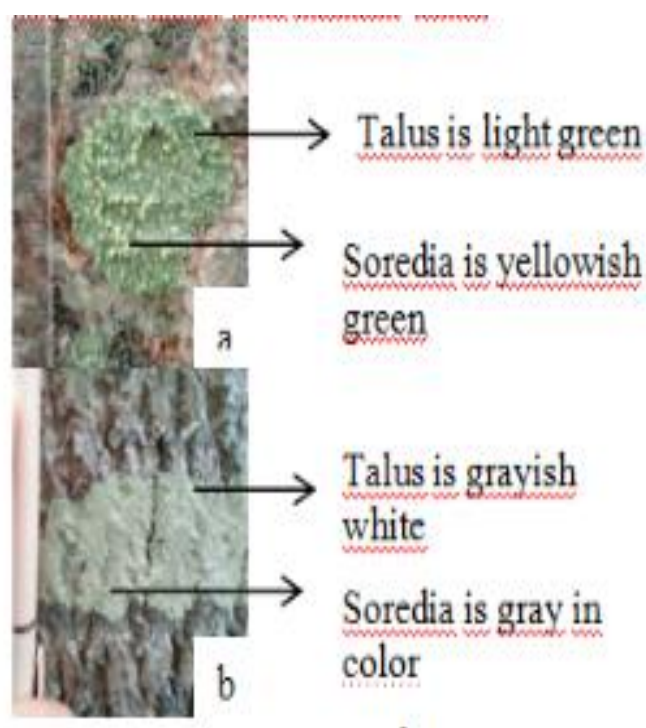

Figure 4. Thallus structures of: a. Dirinaria applanata, b. Dirinaria picta 


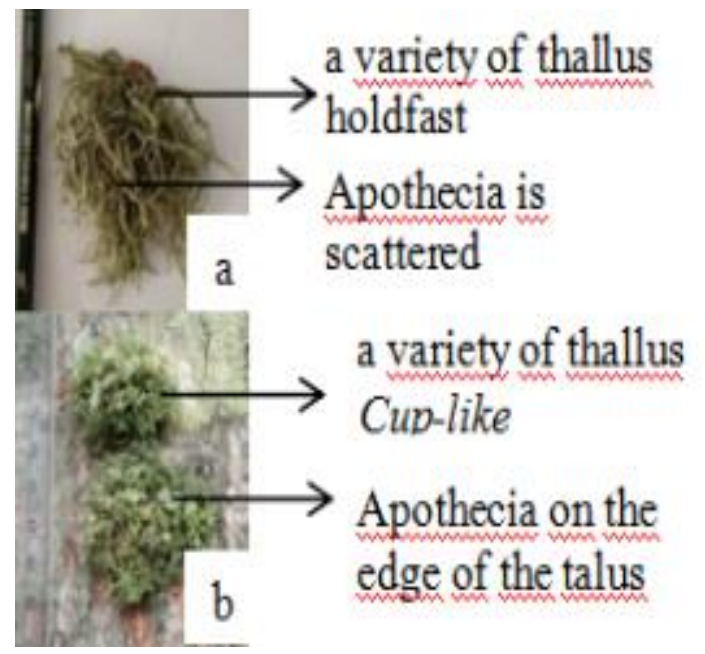

Figure 5. Thallus structures of: a. Ramalia farinaceae, b. Ramalina fastigiate

In the group A1b1b, Parmotrema tinctorum belongs to Parmelia hypoleucina and Parmelia sulcata because it has similar characters in lower cortical color, presence or absence of rhizine, color, rhizine range, does not have apothecia, lirellae, perithecia, fibrils, soredia, has isidia, type of isidia, and location isidia, has the same photobiont type and color. At the similarity coefficient of 0.70 the A2 group is divided into two groups, namely the $\mathrm{A} 2 \mathrm{a}$ and $\mathrm{A} 2 \mathrm{~b}$ groups. This group has the same character, has a plate apothecium, does not have a prothallus, and does not have a labia.

The A2a group consists of seven species, namely, Ramalina farinaceae, Ramalina fastigiata, Ramalina leptocarpha, Lecanora pulicaris, Lecanora helva, Lecanora leprosa, and Megalospora tuberculosa. In the A2a group the species Ramalina farinaceae and Ramalina fastigiata are closely related with a similarity coefficient of 0.96 , the distinguishing characters of these species are variations in the thallus, and the location of the apothecia. In this group the species Lecanora helva and Lecanora lepros were closely related with a similarity coefficient of 0.98 , the distinguishing character of these species on the margin of the apothecia of the plate.

The A2b group consisted of two species, namely Physcia integrata and Physcia stellaris. Similarity of characters in this group has apothecia plate, does not have prothallus, lirellae, labia, perithecia, and fibrils. In this group Physcia integrata, and Physcia stellaris are closely related with a similarity coefficient of 0.92 distinguishing characters of these species, thallus color, apothecia type, and apothecia margin.
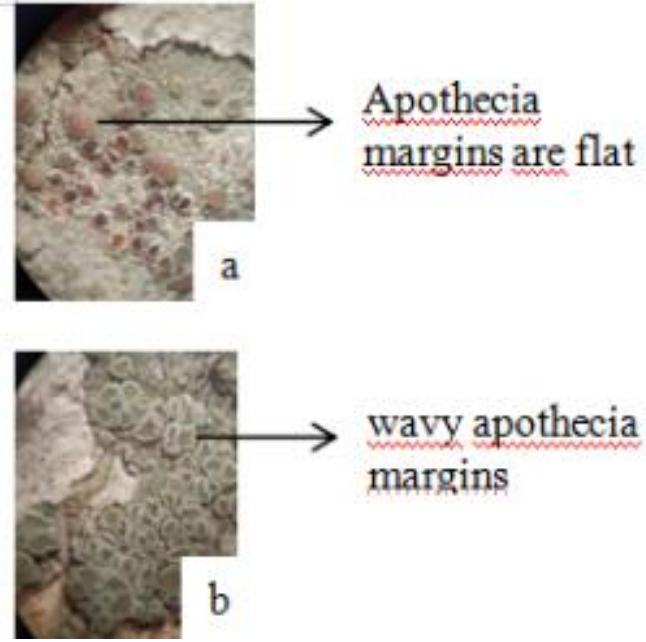

Figure 6. Thallus structures of: a. Lecanora helva, b. Lecanora leprosa

The main group B consists of nine species, lichens in this group have the type of crustose thallus. The similarity of characters in this group is that they do not have lower cortex, do not have soredia, have plate apothecia and some species have apothecia lirellae and perithecia. At a similarity coefficient of 0.65 , the main group B was divided into two groups, namely groups B1 and B2. The characters that separate this group are the presence of prothallus, perithecia, apothecia lirellae, and labia. In group B1 there were two species, there are Cryptothecia striata and Pyrenula macrospora.The characters that distinguish this species are the colors of the thallus, prothallus, and perithecia. Group B2 consists of seven species, namely, Phaeographis intricans, Glyphis cicatricosa, Sarcographa labyrinthica, Graphis plagiocarpa, Graphis vulgata. Graphis scripta, and Dyplolabia afzelii. All species of group B2 have a crustose thallus type, do not have a lower cortex, do not have plate apothecia.

The lichens that have the closest kinship value based on their characters are Lecanora helva and Lecanora leprosa, with a similarity coefficient of 0.98. Then Usnea hirta and Usnea barbata, Dirinaria apllanata and Dirinaria picta, Ramalina farinaceae and Ramalina fastigiata, with a similarity coefficient of 0.94. According to [12] analysis of close kinship relationships if the level of character similarity is above $60 \%$. From the analysis of kinship lichens on tree African wood (Maesopsis eminii Engl.) lichen has a close kinship between species of the species that is more due to similarity coefficients ranged from 0.54 to 0.98 . From the results of the research, it is known that there are 50 species of lichens found on African wood trees (Maesopsis 
eminii Engl.) in the Tangsi Baru Village Tea Plantation, including in Divison Ascomycota, with three classes, five orders, and 10 families. Based on the morphological characters, the phenogram of lichens was divided into two main groups A and B with a similarity coefficient ranging from 0.54 to 0.98 .

\section{CONCLUSION}

It was determined 31 species of lichens with 3 types of thallus; 13 species of crustose thallus, 12 species of foliose thallus, and 6 species of fruticose thallus. The lichens relationship phenogram showed a similarity coefficient ranging from 0.54 to 0.98 , divided into 2 main groups A and B. Main group A consisted of 22 species; 6 species of fruticose lichenes, 12 species of foliose lichenes and 4 species of crustose lichens. Main group B meanwhile, consisted of 9 species of crustose lichens. There were two species of one genus of lichens with a similarity coefficient of 0.98 which shows the similarity of almost all characters, namely Lecanora helva and Lecanora pulicaris. A distinguishing character is on the apothecia margin.

\section{ACKNOWLEDGMENT}

Thank you to the Biology Undergraduate Study Program, University of Bengkulu for providing funds, as well as the dedicated field team.

\section{REFERENCES}

[1] N.A. Campbell, J.B. Reece, L.G. Mitchell, Biologi Jilid 2 Edisi Kelima, Jakarta, Erlangga, 2003. [In Bahasa Indonesia]

[2] J. Cain, G.A. Harrison, Phyletic Weighting, Proceedings of The Zoological Society of London, London, $1960 . \quad$ DOI: https://doi.org/1111/j.14697998.1960.tb05828.x

[3] Rideng, I. Made, Taksonomi tumbuhan biji, Jakarta, Dekdikbud, 1989. [In Bahasa Indonesia]

[4] D.K. Upreti, P.K. Divakar, R. Bajpai, Recent Advances in Lichenology, New Delhi, Springer, 2015 .

[5] T.H. Nash, Lichen Biology. Cambridge UK, Cambridge University Press, 2008.
[6] V. Ahmadjian, The Lichens Symbiosis, New York Simultaneously in Canada, 1967.

[7] T. Goward, The lichens of British Columbia, Illustrated Keys, Special Report Series, Ministry of Forests, Research Program, Victoria, 1999.

[8] F.J. Rohlf, User Guide of NTSYSpc Numerical Taxonomy and Multivariate Analysis System, New York, Department of Ecology and Evolution State University of New York, 1998.

[9] W. Purvis, Adaptation and interaction of saxicolous crustose lichen with metals, Journal Botanical Studies. (2014) Hal 23-55. DOI: https://doi.org/10.1186/1999-3110-55-23

[10] Handoko, R.K. Tohir, Y. Sutrisno, D.H. Brillianti, D. Tryfani, P. Oktorina, P. Yunita, A. N. Hayati, Keanekaragaman lumut kerak (lichens) sebagai bioindikator kualitas udara di Kawasan Asrama Internasional IPB, Jurnal IPB, (2015). [In Bahasa Indonesia]

[11] V. Wirth, The lichens: D. Anderegg (Eds), Stuttgart, University of Regensburg Press.

[12] Ulfira, Keanekaragaman lichenes di sekitar Kampus Uin Ar-Raniry sebagai bioindikator udara pada mata kuliah ekologi dan masalah lingkungan, Undergraduate Thesis, Universitas Islam Negeri Ar-Raniry Darussalam, (2017). [In Bahasa Indonesia]

[13] Asnah, Inventarisasi lumut kerak (lichenes) epifit di Hutan Wisata Loang Gali, Lenek Rambak Biak, Lombok Timur, Undergraduate thesis, Skripsi, Universitas Islam Negeri Mataram, (2018). [In Bahasa Indonesia]

[14] G. Weerakon, Fascinating lichens of Sri Lanka, Colombo, Ceylon Tea Services PLC, 2015.

[15] R. Furi, Eksplorasi Lichen di Sepanjang Jalan Raya SoloTawangmangu dan Kawasan Hutan Sekipan Karanganyar Jawa Tengah, Undergraduate Thesis, Universitas Muhammadiyah Surakarta, (2016). [In Bahasa Indonesia]

[16] G. Singh, Plant Systematic, New Hampshire, Science Publisher, Inc, 1990. 